\title{
The Relationship between Hard Skill and K3 Behavior on Students' Welding Practice of State Vocational High School 2 Bitung
}

\author{
Parsaoran Tamba ${ }^{1}$, Djoko Kustono ${ }^{2}$, Purnomo $^{3}$, Tuwoso ${ }^{4}$ \\ ${ }^{I}$ (Vocational Program, Universitas Negeri Malang, Indonesia) \\ ${ }^{2}$ (Faculty of Technique, Universitas Negeri Malang, Indonesia) \\ ${ }_{3}^{3}$ (Faculty of Technique, Universitas Negeri Malang, Indonesia) \\ ${ }^{4}$ (Faculty of Technique, Universitas Negeri Malang, Indonesia)
}

\begin{abstract}
Health and Safety (K3) and to determine whether there is influence on K3 hard skills behavior (occupational safety and health) welding practices. The object of this research was grade 10 program machining expertise and research sites held on machining skills programs state vocational high School 2 Bitung of North Sulawesi province Indonesia. Based on the type of research is a survey research in which data are collected through a questionnaire to describe the characteristics of the population. The data Analysis was used by correlation and regression analysis. The results indicate that there is influence between hard skills (Variable X) to conduct Health and Safety (K3) (Variable $Y$ ) by $61 \%$ and this effect can be explained by the regression equation $Y=-6.99+0.102 X$
\end{abstract}

Keywords: Hard Skill, K3 behavior

\section{Introduction}

National development which took place in all areas of activity had a positive impact on economic development and prosperity of the nation, because it would open work opportunities. But on the other hand the development of employment opportunities, especially in the field of industrial hazardous condition that could hamper the development processes itself. This potential hazard if not controlled can cause workplace accidents, fire / explosion and environmental pollution. When an accident or incident occurred at the company, according to the Board of the National Occupational Safety and Health (1993) will cause losses of 3 disadvantages: 1) human, 2) Asset, and 3) demands for compensation. With their three losses confirmed the company would not be able to operate again.

The law no. 1 of 1970 set up mechanism for the implementation and supervision of occupational safety and occupational safety requirements in each workplace, so that hazards can be reduced and labor protection can be improved. The law was issued by government, industry or company should be able to suppress the incidence of occupational accidents, but in fact the incidence of occupational accidents still occur in various activities or jobs (Heni, 2011).

According to Wowo (2014) stated that accidents can result from two causes, they are unsafe acts and unsafe conditions. According to the International Labour Organization (ILO) states that $88 \%$ of workplace accidents caused by unsafe acts, and $10 \%$ due to unsafe conditions and $2 \%$ due to an unexpected condition (Kustono, 2016). Research Du Pont and others indicate that 80 to 90 percent of the accidents are the result of unsafe actions than unsafe conditions (Terry E McSween, 2003). And unsafe behavior that is an action is not safe for someone who works that often done the cause of errors in all employment systems (June Daalmans, 2013). The errors on all systems, one is the incidence of workplace accidents. Therefore, to reduce accidents at work, one must behave Health and Safety (K3). K3 Behavior is the action of someone to apply the principle of $\mathrm{K} 3$ workplace. When someone is able to apply the principle of $\mathrm{K} 3$, then the person will be safe in doing the job, so that accidents at work can be avoided. One way a person can apply K3 behavior in the workplace with a hard skill to master

According to Peggy (2007) hard skills refer to the technical ability and the factual knowledge needed to do the job. While the opinion Marando Anne (2012) states that the hard skills "on the other hand, that is the more technical aspects. Meanwhile, according to Endang (2015) hard skill is mastery of science, technology and engineering skills. Observing the opinion of Peggy, Anne Marando and Endang, it can be concluded that the hard skills is the ability of someone to master all forms of knowledge (theory and practice) in all studied any field, so that they can apply in any job. Occupational Safety and Health (K3) hard skill is indispensable in any job, especially in engineering, whereby Occupational Safety and Health (K3) into a mandatory rule to be applied in the workplace. Because of its rules, it applies throughout the world and are obliged to implement the Occupational Safety and Health in the workplace. The deal the world level era of globalization and the free 
market of the WTO (World Trade Organization) and GATT (General Agreement on Tarrffs and Trade) which will take effect in 2020, health and safety (Occupational Safety and Health) is one of the terms of the relationship economic trade in goods and services between countries which must be met by all member states, including Indonesia.

Vocational schools which are growing in Indonesia are an institution of education to produce workforce-ready. The Occupational Safety and Health (K3) is a field of science required to learn vocational high schools. According to Benjamin O. Ali (2008) occupational safety and health (OSH) is generally defined as the science of the anticipation, recognition, evaluation and control of hazards Arising in or from the workplace that could impair the health and well-being of workers, taking into account the possible impact on the surrounding communities and the general environment. Meanwhile, according to Mark A. Friend and James P. Kohn (2007) occupational safety and health is concerned with preserving and protecting human and facility resources in the workplace.

According to Benjamin O. Ali, Mark A. Friend and James P. Kohn that science (Science) K3 is the study of how someone could eliminate an accident at work, so that accidents can be avoided when they are working. Vocational high school science K3 is a lesson that must be given to the students. K3 material learned in vocational high schools with regard to: get to know the source of danger in the workplace, controlling workplace hazards, recognize personal protective equipment (PPE) to protect from exposure to hazards in the workplace and know the impact of work-related accidents. By mastering the K3, the vocational high school students while working can make safe behavior, so as to prevent accidents at work.

$\mathrm{K} 3$ behavior is a form of activity or action taken in the work of workers in order to avoid accidents. K3 behavior must be carried out by the worker, because the worker will know when they expect an accident at work and know how to avoid it. K3 usually were applied by person who enable work in good mastery hard skills K3. If one does not master the hard skills K3, then the person may not be able to apply K3 behavior at work According to Heni (2011), Soekidjo (2012), Daryanto (2010), Chizoma (2007) and Skinner (2013) states that knowledge or hard skills related to a person's behavior. This condition shows that when a person is able to master the knowledge K3 (K3 hard skills), then one is likely to apply K3 behavior while doing the job. Vocational high schools give lesson in the form K3. K3 hard skills in students were learned through theoretical knowledge as well as knowledge practices K3. This study is to determine the relationship of the hard skills that have been mastered students to practice welding. The consideration of making the practice of welding work because the students were at risk once the physical hazards and chemical hazard when they perform welding practices.

\section{Methodology}

This study includes quantitative research which was used to determine the causal of the measurement variable (Thomas Glover, 2002). The research variables consisted of two variables, they were hard skill K3 (independent variable) as a variable cause and welding practices $\mathrm{K} 3$ behavioral variables (dependent variable) as a variable effect. To analyze the data, it was used simple linear regression analysis, according to Thomas Glover (2002) simple linear regression analysis can explain the change of variable $X$ (independent variable) to variable $\mathrm{Y}$ (dependent variable). And the relationship between the variables $\mathrm{X}$ and $\mathrm{Y}$ are assumed to be linear, as well as data variables X and Y are normal (McConway K.J, 1999). The population in this study was grade 10 program machining expertise state vocational high School 2 Bitung with a population of 112 students. According to Suharsimi Arikunto (2006) suggests that if the research subject is less than 100, then it is better taken all that research which was population research. Because the populations in these researches were 112 students, then it should do the sampling. The sampling used probability random sampling, because it is based on research data is homogeneous (Sugiyono 2012). And the size of the sample found using equation Slovin (Riduwan, 2011) as follows:

$\mathrm{n}=$

Where:

$\mathrm{n}=$ total number of sample

$\mathrm{N}=$ total number of populatiom

$\mathrm{d}=$ nilai pretition $95 \%$ atau significancy $=0,05$

so:

$\mathrm{n}=$

As the independent variable $(\mathrm{X})$, hard skills that can be defined operationally are academic ability and skills of students who are marked by the mastery of theoretical knowledge and skills associated with $\mathrm{K} 3$ in welding. The instrument used to determine the mastery of knowledge taken by instruments because the test is based on the cognitive aspects of C1 (memory), C2 (understanding), C3 (application), C4 (analysis). As for the skill test instruments $\mathrm{K} 3$ used also on the implementation of $\mathrm{K} 3$ practices. Assessment instrument consisting of two assessment tests, if the correct answer is given a value of 1 , and if the answer to any given value of 0 . After that the results of the score is converted to a scale of 0-100 with the following formula: 
Value $=$ X 100

Where:

Total Score $\quad=$ total number of correct answers

Maximum Score $\quad=$ total number of correct answers is considered

Grating instruments are used, as in tabel.1 below:

Tabel.1 Grid Instrument Hard Skill

\begin{tabular}{|c|c|c|c|c|c|c|}
\hline \multirow{2}{*}{$\begin{array}{l}\text { Knowledge competence } \\
\text { K3 }\end{array}$} & \multirow[t]{2}{*}{ Indicator } & \multicolumn{4}{|c|}{ Cognitive aspect } & \multirow[t]{2}{*}{ Test Item } \\
\hline & & $\mathrm{C} 1$ & $\mathrm{C} 2$ & C3 & $\mathrm{C} 4$ & \\
\hline General knowledge K3 & $\begin{array}{ll}\text { 1. } & \text { State the sense K3 } \\
\text { 2. } & \text { State the purpose K3 } \\
\text { 3. } & \text { mention the cause of the accident }\end{array}$ & $\begin{array}{l}\mathrm{X} \\
\mathrm{X} \\
\mathrm{X}\end{array}$ & & & & $\begin{array}{l}1 \\
2 \\
3,4,5\end{array}$ \\
\hline $\begin{array}{l}\text { Personal protective } \\
\text { equipment (PPE) }\end{array}$ & Explain the various ppe & & $\mathrm{X}$ & & & $\begin{array}{l}6,7,8,9, \\
10\end{array}$ \\
\hline $\begin{array}{l}\text { Working positions and } \\
\text { control equipment }\end{array}$ & $\begin{array}{l}\text { 1. Connecting a safe working position } \\
\text { 2. Safe working equipment }\end{array}$ & & & $\begin{array}{l}\mathrm{X} \\
\mathrm{X}\end{array}$ & $\mathrm{X}$ & $\begin{array}{l}11 \\
12,13,14\end{array}$ \\
\hline cleanliness & $\begin{array}{l}\text { 1. State kinds of occupational diseases } \\
\text { 2. Knowing the cleanliness of the } \\
\text { working environment }\end{array}$ & $\begin{array}{l}\mathrm{X} \\
\mathrm{X}\end{array}$ & $\begin{array}{l}\mathrm{X} \\
\mathrm{X}\end{array}$ & & & $\begin{array}{l}15,16,17, \\
18 \\
19\end{array}$ \\
\hline $\begin{array}{lcl}\text { Skills } & \text { in } & \text { using } \\
\text { equipment } \mathrm{K} 3 & \end{array}$ & $\begin{array}{l}\text { 1.Preparing the tool } \mathrm{K} 3 \\
\text { 2.Examining the } \mathrm{K} 3 \text { welding equipment } \\
\text { 3. Using personal protective equipment } \\
\text { 4. perform welding }\end{array}$ & & & $\begin{array}{l}X \\
X \\
X \\
X\end{array}$ & & $\begin{array}{l}20 \\
21 \\
22 \\
23\end{array}$ \\
\hline
\end{tabular}

Testing should be performed to the test instrument hard skills which students should be tested to test the validity and reliability of the test instrument. Validity test of the correlation coefficient test was used biserial, by the following equation:

$\mathrm{r}_{\mathrm{bis}}=$

Where:

RBIs = correlation coefficient between scores items number $\mathrm{i}$ with a total score

$\mathrm{Xi}=$ average score of total respondents who answered correctly bouts Question $\mathrm{i}$

$\mathrm{Xt}=$ average total score of all respondents

$\mathrm{St}=$ standard deviation score of the total of all respondents

$\mathrm{pi}=$ proportion of correct answers to items numbers $\mathrm{i}$

qi $=$ The proportion of incorrect answers to items numbers $i$

Test item is valid if the correlation biserial score grains larger than the correlation table (RBIs> rtabel) determined at the significance level of 5\% $(\alpha=0.05)$. While the reliability test used Cronbach Alpha coefficients, with the requirements, Cronbach Alpha coefficients greater than 0.6 (r11>0.6)

$\mathrm{r}_{11}=$

Where :

r11 = Value of reliability

$\Sigma \mathrm{Si}=$ Total variance score for each item

St $=$ Variance total

$\mathrm{k}=$ Number of items

As the dependent variable (Y) K3 behavior can be defined concrete actions undertaken K3 students apply principles when performing welding practices. K3 behavioral assessments taken by the assessment tool by using a check list and observe when students perform welding lab activities. K3 behavioral measurements in this study used direct observation recording permanent product type (permanent product recording) using semantic instrument deferential. Deferential semantic instrument consists of two poles, the pole negative and positive pole. The range of instruments semantic deferential seven levels, namely $-3,-2,-1,0,1,2,3$. Indicators observed behavior consists of three stages, namely early behavioral work, behavior at work and the behavior of the working end. Guidelines for assessing the behavior of the student's work as in Table 2 below:

Table.2 rubric assessment K3 (Occupational safety and health)

\begin{tabular}{|l|l|l|}
\hline No & Observation aspect & Observation rubric \\
\hline 1 & Early behavioral work & 1.Using practice clothes \\
& & 2. Clean the work space \\
& & 3.Preparing for welding equipment and personal protective equipment \\
& 4. Controlling welding equipment (wires, welding machine condition, and others) \\
\hline 2 & Behavior at work & $\begin{array}{l}\text { 1.Using personal protective equipment (PPE) when performing welding } \\
\text { 2. Position ergonomics work while doing welding }\end{array}$ \\
\hline 3 & Behavior on working end & 1. Clean the workspace \\
& & 2. Returns welding equipment and personal protective equipment \\
\hline
\end{tabular}

To process the research data used SPSS (Statistical Product and Service Solutions) version 22. 


\section{Hypothesis}

The hypothesis of this study is whether there is an asymmetric relationship between hard skills and K3 behavior in welding practices

\section{Result}

The results of the data collection variables $\mathrm{X}$ (hard skills) that originally shaped 1 and 0 , after converted to a scale of 1-100 can be seen in tabel.3. Before the data is used as a hard skill forecasting, should be tested first with data normality test (parametric statistical terms). Normal test used to look at the degree of fineness of a data distribution (kurtosis) and with the degree of asymmetry of a distribution of data (skewnes). The result of the calculation of kurtosis and skwenes with SPSS applications can be seen in the table. 3 below:

Table. 3 Data Normality Test Results

\begin{tabular}{|l|l|l|l|}
\hline Data & \multicolumn{2}{|l|}{ Test result } & The degree of asymmetry and kurtosis \\
\hline \multirow{4}{*}{ Hard Skill $(\mathrm{X})$} & Skweness & 0,007 & $0,007 / 0,257=0,02$ \\
\cline { 2 - 3 } & Std.Error of Skweness & 0,257 & \\
\cline { 2 - 3 } & Kurtosis & $-0,197$ & $-0,197 / 0,508=-0,38$ \\
\cline { 2 - 3 } & Std.Error of Kurtosis & 0,508 & \\
\hline \multirow{3}{*}{ K3 behavior $(Y)$} & Skwenes & 0,026 & $0,026 / 0,257=0,10$ \\
\cline { 2 - 3 } & Std.Error of Skweness & 0,257 & \\
\cline { 2 - 3 } & Kurtosis & $-0,949$ & $-0,949 / 0,508=-1,86$ \\
\cline { 2 - 3 } & Std.Error of Kurtosis & 0,508 & \\
\hline
\end{tabular}

Data K3 hard skills and behavior was considered normal, if the degree of fineness and the degree of asymmetry lies between -2 to 2 . The results of the calculations and the degree of fineness degree of asymmetry of the data hard skill as a variable $\mathrm{X}$ is 0.02 and -0.38 . Value of 0.02 and -0.38 indicates that the data is hard skill as a variable $\mathrm{X}$ is normal (located between -2 to 2 ). Data normality hard skills can be seen also on the shape of the normal curve (see Figure1). The result of the calculation of the degree of asymmetry and the degree of fineness of behavioral data $\mathrm{K} 3$ as a variable $\mathrm{Y}$ was 0.10 and -1.86 . Value of 0.10 and -1.86 indicates that behavioral data $\mathrm{K} 3$ as a variable $\mathrm{Y}$ is normal (located between -2 to 2). K3 and the normalcy of behavioral data can be seen also on the shape of the normal curve (see Figure 2).

The test results show that the data is hard skill capabilities of K3 (occupational safety and health) students of SMK Negeri 2 Bitung were varied. There is a hard skill capabilities $23.84 \%$ lower (39.13 to 56.52), there are $40.9 \%$ capability was hard skills (60.68 to 69.56) and there is a hard skill capabilities $34.07 \%$ higher (73, 91-100). And when viewed overall average score of students turned out to be hard skills abilities of students of SMK Negeri 2 Bitung on the average criteria $(67,63)$. The test results the behavioral data of K3 showed that K3 behavior (occupational safety and health) students of SMK Negeri 2 Bitung were varied. There are $42.03 \%$ K3 behavior of students while doing practical welding negative ( -3 to -1$)$ ) means that at the time of welding students practice very rarely apply the principle of K3, such as checking the welding equipment, use of personal protective equipment, and cleaning the rooms, etc. There are $20.46 \% \mathrm{~K} 3$ behavior neutral (0) means that when students perform welding practices already apply the principle of $\mathrm{K} 3$, although it is not optimal because it is only apply some of the principles K3 current welding practices. Then there are $37.49 \%$ positive behavior K3 (13 ), meaning that at the time a student is disciplined on welding practice, they apply the principle of K3. when it is viewed from the overall average score of students behavior K3 students of SMK Negeri 2 Bitung when they are carrying out welding practices on neutral criteria $(-0.11)$..

Table. 4 Data Distribution Hard Skill

\begin{tabular}{|l|l|l|l|}
\hline No & Variable X & Total number & Percentage (\%) \\
\hline 1 & 39,13 & 3 & 3,40 \\
\hline 2 & 43,47 & 3 & 3,40 \\
\hline 3 & 47,48 & 4 & 4,55 \\
\hline 4 & 52,17 & 5 & 5,68 \\
\hline 5 & 56,52 & 6 & 6,81 \\
\hline 6 & 60,68 & 9 & 10,22 \\
\hline 7 & 65,21 & 11 & 12,50 \\
\hline 8 & 69,56 & 16 & 18,18 \\
\hline 9 & 73,91 & 10 & 10,22 \\
\hline 10 & 78,26 & 6 & 6,81 \\
\hline 11 & 82,61 & 5 & 5,68 \\
\hline 12 & 86,96 & 4 & 4,55 \\
\hline 13 & 91,30 & 3 & 3,40 \\
\hline 14 & 95,65 & 2 & 2,27 \\
\hline 15 & 100 & 1 & 1,14 \\
\hline Total & & 88 & \\
\hline
\end{tabular}




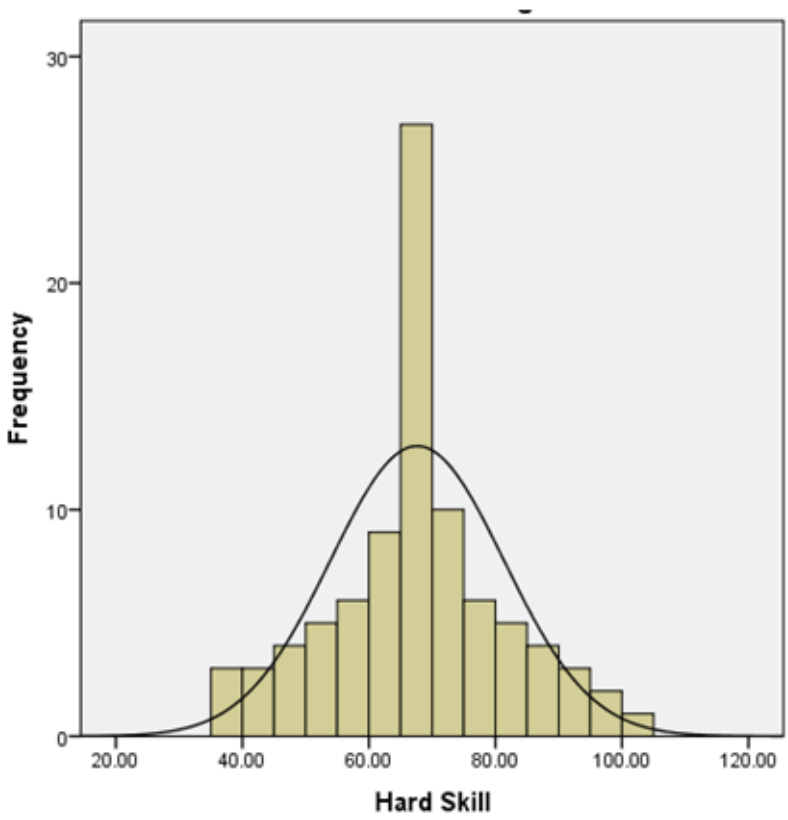

Figure 1 Histogram and Normal Hard Skill curve

Tabel. 5 Distribution Data of K3 behavior

\begin{tabular}{|l|l|l|l|}
\hline No & Variable Y & Total number & Persentage (\%) \\
\hline 1 & -3 & 10 & 11,36 \\
\hline 2 & -2 & 12 & 13,63 \\
\hline 3 & -1 & 15 & 17,04 \\
\hline 4 & 0 & 18 & 20,46 \\
\hline 5 & 1 & 14 & 15,91 \\
\hline 6 & 2 & 12 & 13,63 \\
\hline 7 & 3 & 7 & 7,95 \\
\hline Total & 88 & & 100 \\
\hline
\end{tabular}

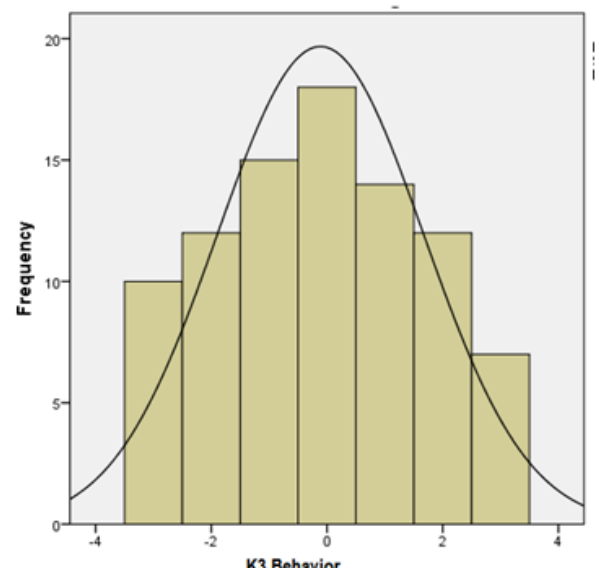

Figure 2 Histogram and Normal curve K3 behavior

The results of data processing were using SPSS application of a symmetrical relationship (correlation) and an asymmetrical relationship (regression) can be seen in tabel.5 and tabel.6, as follows:

Table.5 Symmetrical Relationship Testing Results (correlation)

\begin{tabular}{|l|l|l|l|}
\hline \multicolumn{2}{|c|}{} & Hard Skill & K3 behavior \\
\hline \multirow{4}{*}{ Hard Skill } & Pearson Correlation & 1 & $.781^{* *}$ \\
\cline { 2 - 4 } & Sig. (2-tailed) & & .000 \\
\cline { 2 - 4 } & $\mathrm{N}$ & 88 & 88 \\
\hline \multirow{3}{*}{ K3 behavior } & Pearson Correlation & $.781^{* *}$ & 1 \\
\cline { 2 - 4 } & Sig. (2-tailed) & .000 & 88 \\
\cline { 2 - 4 } & $\mathrm{N}$ & 88 & \\
\hline \multirow{2}{*}{$* *$ Correlation is significant at the 0.01 level (2-tailed). } \\
\hline
\end{tabular}


Table. 6 Results Testing Asymmetrical Relations (regression)

\begin{tabular}{|l|l|l|l|l|l|l|}
\hline \multicolumn{2}{|l|}{ Model } & \multicolumn{2}{|l|}{ Unstandardized Coefficients } & $\begin{array}{l}\text { Standardized } \\
\text { Coefficients }\end{array}$ & \multirow{2}{*}{ Sig. } \\
\cline { 3 - 6 } \multicolumn{2}{|l|}{} & $\mathrm{B}$ & Std. Error & Beta & & \\
\hline \multirow{2}{*}{1} & (Constant) & -6.990 & .605 & & -11.555 & .000 \\
\cline { 2 - 6 } & Hard Skill & .102 & .009 & .781 & 11.595 & .000 \\
\hline \multicolumn{2}{|l|}{ Dependent Variable: Perilaku K3 } \\
\hline
\end{tabular}

Table. 7 Hard Skill Testing Results Influence Behavior toward K3

\begin{tabular}{|c|c|c|c|c|c|c|c|c|c|}
\hline \multirow{2}{*}{$\begin{array}{l}\text { Mode } \\
1\end{array}$} & \multirow[t]{2}{*}{$\mathrm{R}$} & \multirow[t]{2}{*}{ R Square } & \multirow{2}{*}{$\begin{array}{l}\text { Adjusted } \\
\text { R Square }\end{array}$} & \multirow{2}{*}{$\begin{array}{l}\text { Std. Error of the } \\
\text { Estimate }\end{array}$} & \multicolumn{5}{|l|}{ Change Statistics } \\
\hline & & & & & $\begin{array}{l}\text { R Square } \\
\text { Change }\end{array}$ & F Change & df1 & df2 & Sig. F Change \\
\hline 1 & $.781^{\mathrm{a}}$ & .610 & .605 & 1.121 & .610 & 134.446 & 1 & 86 & .000 \\
\hline
\end{tabular}

The test results on tabel.5, tabel.6 and tabel.7 shows that there is a significant correlation between hard skills with $\mathrm{K} 3$ behavior of $(\mathrm{r}=0.781)$. This condition shows when students master hard skills with good abilities, then K3 behavior when performing welding practice very well, that the students always apply the principle of K3 to avoid accidents at work. While hard skills influence the behavior of K3 obtained at ( $\mathrm{r} 2=$ 0.61 ), this condition indicates that the hard skill has a very significant influence on behavior also K3, ie by $61 \%$. Hard skills and influence of the behavior of $\mathrm{K} 3$ can be seen from the regression equation $\mathrm{Y}=\mathrm{a}+\mathrm{b} \mathrm{X}(\mathrm{Y}=-$ $6.99+0.102 \mathrm{X})$, meaning that if students can be improved by 1 hard skill capabilities, they will improve the behavior of $\mathrm{K} 3$ at 0.102 .

\section{Conclusion}

These results indicate that there is a symmetrical relationship (correlation) and an asymmetrical relationship (regression) was significant between hard skills and the behavior of occupational safety and health (occupational safety and health) on welding practices. The capability of K3 hard skill should be mastered when the student will be doing practical welding. By mastering the hard skills, the students will know how to behave safely on the spot welding practices. K3 behave so student can minimize the occurrence of accident while working.

\section{References}

[1]. Anne Marando. 2012. Balancing Project Management. Rabb School of Continuing StudiesDivision of Graduate Professional Studies Brandeis University 2012

[2]. Ajzen, I., \& Fishbein, M. (2005). The influence of attitudes on behavior. In D. Albarracín, B. T. Johnson, \& M. P. Zanna (Eds.), The handbook of attitudes (pp. 173-221). Mahwah, NJ: Erlbaum.

[3]. Benjamin O. Ali (2008). Fundamental Principles of Occupational Health and Safety. Genewa. International Labour Organization

[4]. Chizoma M Ndikom. 2007. Knowledge and behaviour of nurse/midwives in the prevention of vertical transmission of HIV in Owerri, Imo State, Nigeria: a cross-sectional study. Journal BMC Nursing.

[5]. DK3N. 1993. Audit Keselamatan dan Kesehatan Kerja. Jakarta: DK3N

[6]. Daryanto. 2010. Keselamatan dan Kesehatan Kerja Bengkel. Jakarta. Bina Adiaksara

[7]. Heni Yusri. 2011. Improving Our Safety Culture. Jakarta: Gramedia

[8]. Juni Daalmans. Human Behavior in Hazardous Situations. Butterworth-Heinemann is an imprint of Elsevier. The Boulevard, Langford Lane, Kidlington, Oxford, OX5 1GB, UK 225 Wyman Street, Waltham, MA 02451, USA

[9]. Kustono, Djoko. 2016. Ilmu Perilaku Sebagai Strategi Mencegah Kecelakaan Kerja. Pidato Pengukuhan Jabatan Guru Besar Dalam Bidang Ilmu Keselamatan dan Kesehatan Kerja Universitas Negeri Malang

[10]. Mark A. Friend and James P. Kohn. (2007). Fundamentals of Occupational Safety and Health. Maryland. The Rowman \& Littlefield Publishing Group, Inc.

[11]. McConway K.J. 1999. Statistical Modeling Using GENSTAT. New-York. Oxfort University Press Inc.

[12]. Peggy Klaus. 2007. The Hard Truth About Soft Skills. Harper Collins Publishers (Australia) Pty.Ltd. Australia

[13]. Riduwan. 2011. Path Analysis. Bandung: Alfabeta

[14]. Soekidjo Notoatmidjo. 2012. Promosi Kesehatan Dan Perilaku Kesehatan. Jakarta: Penerbit Rineka Cipta

[15]. Santrock W John. 2013. Educational Phsychology. New York: Edition 2 Mc Graw-Hill Company Inc

[16]. Skinner B.F. 2013. Ilmu Pengetahuan dan Perilaku Manusia. Yogyakarta. Pustaka Belajar

[17]. Suharsimi, Arikunto. 2006. Prosedur Penelitian Suatu Pendekatan Praktik. Jakarta, Rineka Cipta

[18]. Sugiyono. 2012. Metode Penelitian Pendidikan. Bandung. Alfabeta

[19]. Tombokan Runtukahu. 2013. Analisi Perilaku Terapan Untuk Guru. Jakarta. Ar-Russ Media

[20]. Thomas Glover. 2002. An Introduction to Biostatistics. New York. Mc Graw-Hill

[21]. Terry E McSween. 2003. Value-Based Safety Process Published (Improving Your Safety Culture WithBehavior-Based Safety). John Wiley \& Sons, Inc., Hoboken, New Jersey.

[22]. Undang-Undang Republik Indonesi No.1 Tahun 1970 Tentang Keselamatan Kerja

[23]. Wowo, Kuswana Sunaryo. 2014. Ergonomi dan K3. Bandung: PT Remaja Rosdakarya 